\title{
Spatial Exposure and Livelihood Vulnerability to Climate-Related Disasters in The North Coast of Tegal City, Indonesia
}

\author{
Iwan Rudiarto $^{1 *}$ and Dony Pamungkas ${ }^{1}$ \\ 1 Department of Urban and Regional Planning, Diponegoro University \\ * Corresponding Author, Email: iwan.rudiarto@pwk.undip.ac.id
}

Received: October 20,2018 Accepted: April 8, 2020

Keywords: Floods, Tidal Floods, Coastal Community, Spatial Assessment, Vulnerability Assessment, Livelihood Vulnerability Index

\begin{abstract}
Climate-related disasters such as floods and tidal floods impact livelihood systems in coastal areas everywhere, particularly in developing countries, resulting in a certain degree of livelihood vulnerability. In this paper, we examine the spatial exposure and livelihood vulnerability level of Tegal, a city in Central Java, Indonesia. Data were collected from 100 household samples distributed in the study area. Two types of assessment were performed: a spatial assessment with distance analysis and a vulnerability assessment using the Livelihood Vulnerability Index (LVI). The results of the study show that $33.80 \%$ of the settlement area and $22.25 \%$ of the fishery area are vulnerable to tidal floods. Climate-related disasters also threaten $32.20 \%$ of the households sampled, whose members work mostly as fishermen and rely on coastal resources for their livelihood. A key finding of the study is that the community is highly vulnerable with a low adaptive capacity level. This calls for more decisive policy interventions to enhance the community's adaptive capacity and reduce its exposure level.
\end{abstract}

\section{INTRODUCTION}

Coastal areas are on the front line of climate change all over the world. The (Intergovernmental Panel on Climate Change, 2007) notes that coastal areas are now facing the worst impacts of climate change. Unpredictable changes in macroclimate cause other natural environmental changes. For example, climate change causes ice to melt in polar regions, which in turn causes sea level rise. According to Nhuan et al. (2009), ecosystems in coastal areas are highly vulnerable, impacted by coastal hazards such as typhoons, storms, erosion, pollution, global climate change and sea level rise. Whilst these phenomena vary considerably at regional and local levels, their impacts will certainly be devastatingly negative (Pinto \& Martins, 2013). The impact of sea level rise is evident in coastal areas, where it creates a risk of tidal floods (McGranahan, Balk, \& Anderson, 2007). However, the risk of tidal floods in coastal areas is not due to sea level rise alone; earthquakes can also trigger tsunamis, such as the South Asian tsunami of 2004 and the tsunami in Palu, Indonesia, in 2018, where coastal communities experienced severe damage.

In many coastal areas, disasters are the major cause of livelihood deterioration among coastal communities and threaten socioeconomic sustainability (Fakhruddin \& Rahman, 2015; Nanlohy et al., 2015). Generally, a disaster is 
defined as a phenomenon caused by natural or human factors that can threaten the lives and livelihoods of communities and that may generate casualties, environmental damage, property loss and psychological impacts (Badan Nasional Penanggulangan Bencana (BNPB), 2012). Solidity very much depends on people's resilience and the ability of affected people to recover (Daramola et al., 2016). On the other hand, coastal areas in developing countries are typically rural, and their communities often depend either directly or indirectly on the variety and productivity of coastal resources in their vicinity (Osbahr et al., 2008; Shah et al., 2013). The livelihoods of coastal communities are thus strongly linked to the wellbeing of coastal and marine ecosystems (Allison et al., 2009; Ferrol-Schulte et al., 2015). Their level of vulnerability to climate change is determined by their ability to cope with climate change impacts (Dolan \& Walker, 2006). Adger, W. Neil (2006) explained the vulnerability concept in negative terms as a susceptibility to being harmed.

In terms of response to climate change, a vulnerability assessment is acknowledged as a common tool for identifying the existence of impairment in a human and ecological system in a specific area (Adger, W Neil et al., 2007). By knowing the level of vulnerability, different kinds of scenarios can be proposed to address local issues (Ford \& Smit, 2004; Preston, Yuen, \& Westaway, 2011). Researchers use various methods and approaches to assess the degree of vulnerability from different perspectives, such as the physical environment, socioeconomic development, or a combination of both. The focus of the assessment is the human population who directly experience the effects of climate-related disasters.

The human vulnerability assessment was previously proposed by $\underline{\text { Cutter, }}$ Boruff, and Shirley (2003) using a social vulnerability index. This assessment emphasized the human vulnerability to environmental hazards and then extended it to different kinds of hazards such as floods (Bjarnadottir, Li, \& Stewart, 2011; Flanagan et al., 2011; Tucker et al., 2015). Depending on the type of assessment, either socioeconomic or physical environments, or both, are included in social vulnerability evaluations (Mainali \& Pricope, 2019). However, most vulnerability assessments have been carried out using only secondary data referring to specific administrative areas (such as the national or regional level), rendering the results inaccurate, particularly at the local level (De Sherbinin et al., 2015). Assessment on a local scale using local socioeconomic data (either a micro-level survey or census data) can describe community livelihood much more accurately, but it presents a serious challenge for researchers compiling vulnerability assessment indices (Eriksen \& Kelly, 2007; Gao et al., 2014; Handayani et al., 2017; Huong, Yao, \& Fahad, 2019; Kumar, Geneletti, \& Nagendra, 2016; Preston, Yuen, \& Westaway, 2011; Rasch, 2016). Hahn, Riederer, and Foster (2009) proposed a Livelihood Vulnerability Index (LVI) to assess human vulnerability to climate change, using socioeconomic data collected exclusively from primary sources as representative of the region.

The objective of this article is to identify the distribution of spatial exposure and to find out the level of livelihood vulnerability in a specific coastal area that is prone to floods and tidal floods. Further, the article attempts to determine which areas are more or less exposed to sources of disaster, as well as which vulnerability component is more or less relevant. A livelihood vulnerability assessment is significant because it takes into consideration all the population's assets in a specific region, including natural, physical, human, financial and social capital. It also examines all the necessary activities and accesses to resources that determine the living level of each individual or household (Ellis, 2000).

In this study, we used LVI and combined LVI-IPCC indices to assess the level of vulnerability to climate-related disasters of people living in the coastal area in 
West Tegal sub-district, Central Java, Indonesia. The choice of the LVI method (Hahn, Riederer, \& Foster, 2009) as a vulnerability assessment tool is on account of its ability to assess both physical and socioeconomic aspects, whereas previous assessments focused primarily on the physical aspects of a disaster (Eakin \& Luers, 2006). On the other hand, the (Intergovernmental Panel on Climate Change (IPCC), 2001) model has been used by many scholars and is considered a powerful tool for vulnerability assessment. Combining the LVI and IPCC indices makes the vulnerability assessment more comparable. Though studies on vulnerability assessment are commonly found, the results may describe different levels of vulnerability as the LVI is location-specific, i.e. closely related to local socioeconomic characteristics and the surrounding environment in a particular location (Turner et al., 2003).

\section{LIVELIHOOD VULNERABILITY}

The degree of vulnerability of any system is reflective of the exposure and sensitivity of the concerned system to risk circumstances or adverse effects, and its ability to cope, adapt or recover from the effects of these conditions (Bosello \& De Cian, 2014; Smit \& Wandel, 2006). Thus, vulnerability is a function of exposure, sensitivity and adaptive capacity (Intergovernmental Panel on Climate Change, 2007; Yoo, Kim, \& Hadi, 2014; Glick, Stein, \& Edelson, 2011). The vulnerability level in a certain region can be perceived from its exposure to the negative impacts of climate change; sensitivity is the responsiveness that renders it more or less susceptible to exposure, and adaptive capacity is the ability to cope with the impacts of climate change (Buotte et al., 2016; Intergovernmental Panel on Climate Change, 2007). Exposure to climate change can be explained by the characteristics, magnitude and rate of climate variation (Ebi, Kovats, \& Menne, 2006). Sensitivity refers to the magnitude of a system's response to an external disturbance; it can be positive or negative (Allison \& Ellis, 2001; Shah et al., 2013). While adaptive capacity has a positive impact on vulnerability, it depends on local livelihood options and strategies (Dulal et al., 2010).

The livelihood vulnerability assessment using the LVI is an adjusted form of the Sustainable Livelihood Approach (SLA), which was used previously by the United Nations. The SLA considers five types of assets: natural, social, financial, physical and human (Ferrol-Schulte et al., 2015; Glavovic \& Boonzaier, 2007). It captures the sensitivity level and adaptive capacity of communities while also integrating exposure to climate change (Hahn, Riederer, \& Foster, 2009). The livelihood approach in climate change vulnerability assessments can also be used to understand the impacts of environmental changes (Shameem, Momtaz, \& Rauscher, 2014). A sustainable livelihood can be achieved if a community is able to cope with, and recover from, stresses and shocks while also maintaining or enhancing its capabilities and assets without devastation to its natural resources (Khayyati \& Aazami, 2016). There are seven main components of a livelihood vulnerability assessment conducted using LVI: socio-demographic profiles, livelihood strategies, social networks, health assurance, water resources, housing, and the variability of climate and natural disasters.

In practice, a vulnerability assessment encompasses two major aspects: the comparison of vulnerability within the community, and determining which component drives the level of vulnerability inside the community (Intergovernmental Panel on Climate Change (IPCC), 2001). In this regard, the IPCC model is an influential analytical tool applied by many researchers. An indicator-based vulnerability assessment was developed by Hahn, Riederer, and Foster (2009) within the framework introduced by the IPCC and has been used in 
various contexts (Madhuri, Tewari, \& Bhowmick, 2014; Panthi et al., 2016; Shah et al., 2013; Tjoe, 2016; Can, Tu, \& Hoanh, 2013). The LVI proposes three types of indices and then draws comparisons based on the different indicators. The LVI is a composite index of the seven main components described above, while in the IPCC approach these seven components are grouped into three vulnerability variables: exposure, sensitivity and adaptive capacity. However, different methods for assessing vulnerability are available, with various highlights and components; there is no consensus on which method is ideal (Huong, Yao, \& Fahad, 2019). Where weighted models are applied, some research may apply equally-weighted components and others may not. The definition of the LVI and the use of a combined LVI-IPCC approach are aimed to help practitioners, researchers and policymakers with an easy-to-use tool for assessing vulnerability to climaterelated disasters at varying local levels.

\section{STUDY AREA}

The study area for this research is located in the West Tegal sub-district of Tegal city, Indonesia, as shown in Figure 1. This area was chosen because the majority of its inhabitants work as fishermen, whose livelihoods are especially vulnerable to coastal climate disasters. Though part of the city of Tegal, West Tegal sub-district has its own characteristics; its sought-after location has resulted in intense urbanization, making it prone to coastal disasters (Handayani et al., 2017). According to Gibbes, Southworth, and Keys (2009), a community's dependence on wetlands tends to increase with physical proximity. The subdistrict consists of seven urban villages (known as kelurahan): Pesurungan Kidul, Kraton, Debong Lor, Tegalsari, Kemandungan, Muarareja and Pekauman.

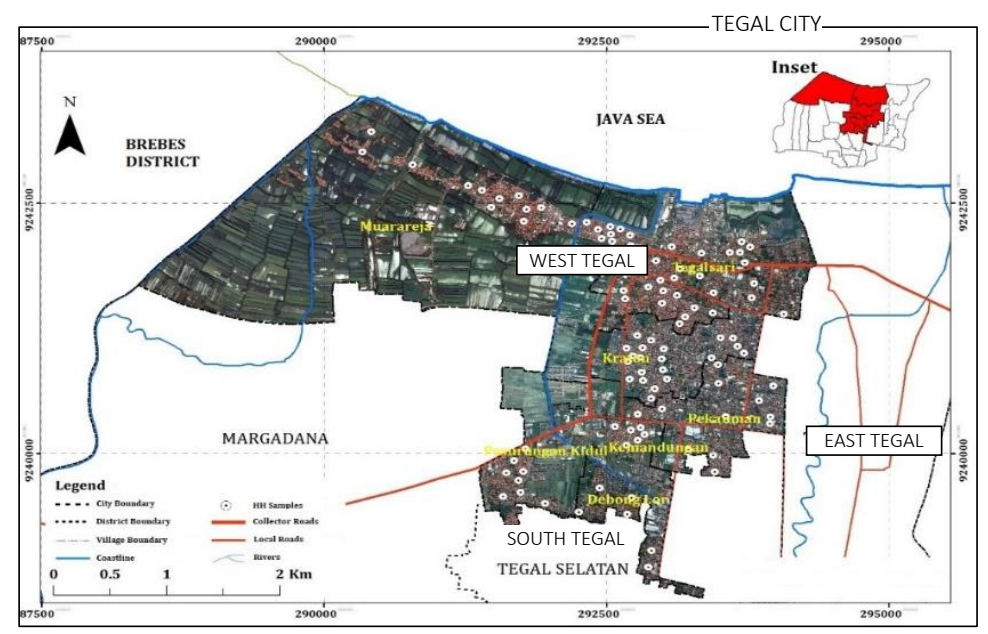

Figure 1. Study area and distribution of sampled households

West Tegal is the largest of four sub-districts in Tegal, a medium-sized city in the northern part of Central Java with a total surface area of $39.68 \mathrm{~km}^{2}$. The West Tegal sub-district occupies about $38 \%$ of the city's total area, or $15.13 \mathrm{~km}^{2}$. A total of 276,734 people reside in Tegal, $24.7 \%(68,354)$ of whom live in West Tegal. The population density of West Tegal is about 4,518 people $/ \mathrm{km}^{2}$, or 0.6 times that of the city, which has an overall density of 6,974 people $/ \mathrm{km}^{2}$.

Like other coastal areas in Tegal, West Tegal experiences climate-related disasters such as tidal floods, flash flooding and flood inundations (Handayani et al., 2019). Tidal floods take place due to land subsidence and sea-level rise. Flash flooding is the consequence of the ground's inability to absorb all the rainfall and the poor condition of drainage infrastructure. Flood inundations can occur in 
densely populated urban areas with poor drainage systems. Figure 2 shows the physical condition of settlement in the study area.
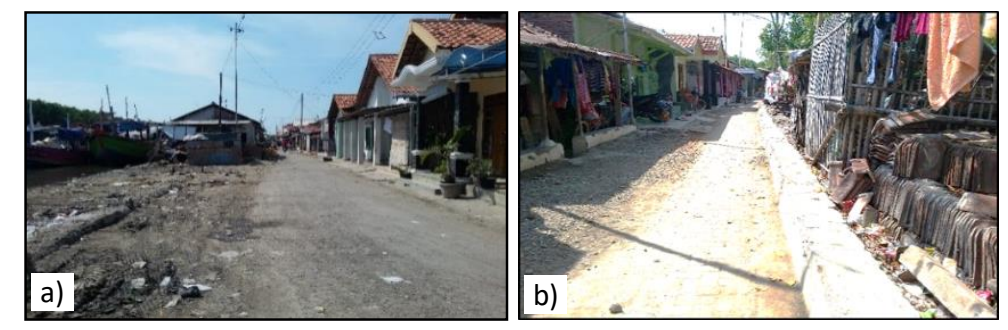

Figure 2. (a) Settlement adjacent to river and (b) settlement equipped with dyke

\section{DATA AND METHODS}

\subsection{Data collection}

In this study, data collection was performed by a micro-level survey with questionnaire distribution at the household level. The micro-level survey was intended to capture real vulnerability conditions as the information came directly from the source. To fulfil the data requirements of a micro-level survey, a random sampling technique was applied to select 100 households in the study area. Simple random sampling ensured that every sample unit had an equal chance of being selected for this research.

Standardized questionnaires were distributed to collect data about livelihood

conditions in the study area. The questionnaire was intended to collect information on the characteristics and typologies of each household with respect to livelihood vulnerability to floods and tidal floods. These characteristics and typologies include socio-demographic profiles, livelihood strategies, social networks, health conditions, water resources, housing and the variability of natural disasters and climate.

One of the main obstacles in data collection - besides finding available households - was the varying level of education of the participants. Those with a higher level of education understood the questionnaire relatively well, but more effort was required to explain the questions to less educated participants. Therefore, adequate skills and knowledge in dealing with the local situation were very important. See Figure 1 for sample distribution in the study area.

\subsection{Assessing the spatial exposure of sampled households}

Assessment of spatial exposure was performed by comparing the location of distributed household samples to the source of climate-related disasters, such as coastline and rivers, and grouping the level of climate-related disasters into particular classes. The comparative analysis was intended to measure how far the household samples were from a disaster source. This was done through a distance analysis. To get the final result on how far a sampled household was from a source of disaster, a cross-classification between the number of sampled households and distance was employed. However, physical variables such as road system, topography and elevation were expected to affect the results. The possibilities for cross-classification in this analysis are shown in Figure 3. 


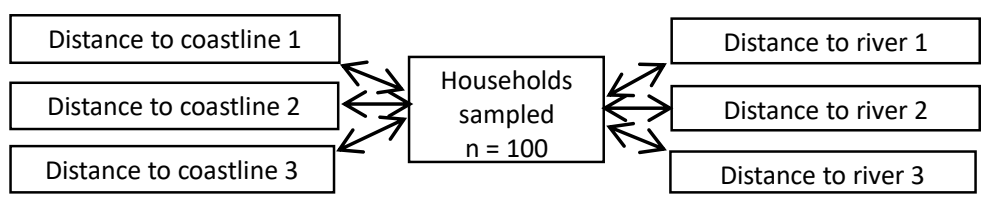

Figure 3. Combination typology of cross-classification

Meanwhile, grouping analysis was applied in order to identify the classified frequency of a climate-related disaster that occurred in the study area. A spatial interpolation approach was employed to estimate the value of disaster intensity in a specific location from the household survey data. According to Zhang and Goodchild (2002), spatial interpolation methods estimate the variables at unobserved locations in the geo-space based on the values at observed locations. By applying the interpolation method, data for the whole study area can be generated, including for areas where no data were available (Rudiarto, Handayani, $\&$ Sih Setyono, 2018).

This study used the Inverse Distance Weighting (IDW) interpolation method. However, this method can yield unrealistic values, especially at the edge of the study surface. To avoid this, Lentes (2003) suggests classifying the grid layers into the desired classes. Desirable classes divide grid layers into specific divisions, leading to subtler results. The calculation of the interpolation method is derived from a weighted mathematical function, which can be described as follows (Shekhar \& Xiong, 2007):

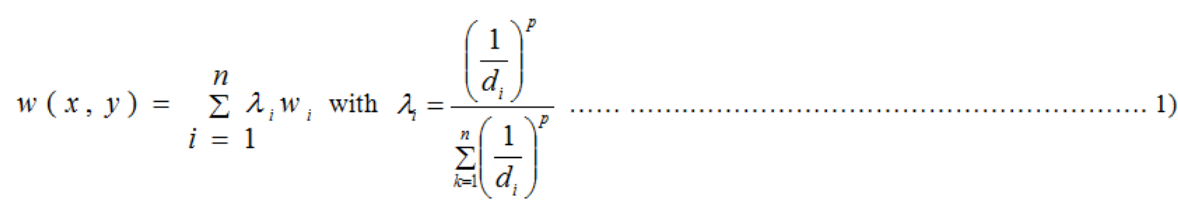

In Equation $(1), w(x, y)$ is the predicted value at location $(x, y), n$ is the number of nearest known points surrounding $(x, y), \lambda_{i}$ are the weights assigned to each known point value $w_{i}$ at location $\left(x_{i}, y_{i}\right), d_{i}$ are the two-dimensional Euclidean distances between each $\left(x_{i}, y_{i}\right)$ and $(x, y)$, and $p$ is the exponent, which influences the weighting $w_{i}$ on $w$.

\subsection{Assessing the Livelihood Vulnerability Index (LVI)}

The LVI model used in this study was based on previous research by Hahn, Riederer, and Foster (2009) and Shah et al. (2013). Following these two studies, with some modification, seven main components for livelihood vulnerability assessment were selected: socio-demographic profiles, livelihood strategies, social networks, health, water resources, housing and natural disaster and climate variability (see Table 1 for details). However, we are aware that infrastructure conditions and level of development may also significantly influence the vulnerability of a community. Since our intention is to describe the level of livelihood vulnerability, we assess livelihood from the household perspective.

Table 1. Livelihood Vulnerability Index (LVI) design

\begin{tabular}{lll}
\hline $\begin{array}{l}\text { Main component / } \\
\text { sub-component }\end{array}$ & $\begin{array}{l}\text { Measuring } \\
\text { unit }\end{array}$ & Sub-component explanation \\
\hline Socio-demographic profiles & ratio & $\begin{array}{l}\text { Dependency ratio of the household's } \\
\text { members under 15 and over 65 years of age } \\
\text { to the household's members between } 19 \text { and } \\
\text { (1) Dependency ratio }\end{array}$ \\
& & \\
\hline
\end{tabular}




\begin{tabular}{|c|c|c|}
\hline $\begin{array}{l}\text { Main component / } \\
\text { sub-component }\end{array}$ & $\begin{array}{l}\text { Measuring } \\
\text { unit }\end{array}$ & Sub-component explanation \\
\hline $\begin{array}{l}\text { (2) Percentage of households } \\
\text { where the head of the } \\
\text { household did not attend } \\
\text { school }\end{array}$ & percent & $\begin{array}{l}\text { Percentage of households where the head of } \\
\text { the household did not complete primary } \\
\text { school. }\end{array}$ \\
\hline $\begin{array}{l}\text { (3) Average number of family } \\
\text { members in household }\end{array}$ & $\begin{array}{l}\text { number of } \\
\text { persons }\end{array}$ & $\begin{array}{l}\text { Average number of members of each } \\
\text { household who live in the same home. }\end{array}$ \\
\hline \multicolumn{3}{|l|}{ Livelihood strategies } \\
\hline $\begin{array}{l}\text { (4) Percentage of households } \\
\text { that depend on the coastal } \\
\text { resources for their income }\end{array}$ & percent & $\begin{array}{l}\text { of households that ha } \\
\text { tal sector as their prima }\end{array}$ \\
\hline $\begin{array}{l}\text { (5) Percentage of households } \\
\text { that have livelihood } \\
\text { alternatives }\end{array}$ & percent & $\begin{array}{l}\text { Percentage of households that have } \\
\text { livelihood alternatives to support their main } \\
\text { income, in the coastal sector or other. }\end{array}$ \\
\hline $\begin{array}{l}\text { (6) Percentage of households } \\
\text { that have saving ability }\end{array}$ & perc & $\begin{array}{l}\text { Percentage of households that have saving } \\
\text { ability to cope with hazard events. }\end{array}$ \\
\hline \multicolumn{3}{|l|}{ Social networks } \\
\hline $\begin{array}{l}\text { (7) Percentage of households } \\
\text { who asked for help from } \\
\text { their neighbourhood or local } \\
\text { government in the previous }\end{array}$ & percent & $\begin{array}{l}\text { Percentage of households who asked for } \\
\text { help from their neighbourhood or local } \\
\text { government in the form of financial aid or } \\
\text { other. }\end{array}$ \\
\hline
\end{tabular}
12 months

\begin{tabular}{|c|c|}
\hline \multicolumn{2}{|l|}{ Health } \\
\hline $\begin{array}{l}\text { Average time needed to minutes } \\
\text { reach a health facility }\end{array}$ & $\begin{array}{l}\text { Average time needed to reach the closest } \\
\text { health facility, such as the local public health } \\
\text { centre/puskesmas or hospital. }\end{array}$ \\
\hline $\begin{array}{l}\text { (9) Percentage of households percent } \\
\text { that do not have health } \\
\text { insurance }\end{array}$ & $\begin{array}{l}\text { Percentage of households that do not have } \\
\text { health insurance to cope when they become } \\
\text { ill. }\end{array}$ \\
\hline \multicolumn{2}{|l|}{ Water resources } \\
\hline $\begin{array}{l}{ }^{(10)} \text { Percentage of households percent } \\
\text { that use natural water } \\
\text { resources }\end{array}$ & $\begin{array}{l}\text { Percentage of households that obtain their } \\
\text { clean water from a source other than a local } \\
\text { water company, i.e. from a well, river, } \\
\text { rainwater harvesting or other. }\end{array}$ \\
\hline
\end{tabular}

\begin{tabular}{|c|c|c|}
\hline \multicolumn{3}{|l|}{ Housing } \\
\hline $\begin{array}{l}\text { (11) Percentage of homes that } \\
\text { are vulnerable to disasters }\end{array}$ & percent & $\begin{array}{l}\text { Percentage of dwellings that are vulnerable } \\
\text { to disasters, such as tidal floods or local } \\
\text { floods. }\end{array}$ \\
\hline $\begin{array}{l}\text { (12) Percentage of homes that } \\
\text { did not raise their floor to } \\
\text { prevent flood hazard }\end{array}$ & percent & $\begin{array}{l}\text { Percentage of dwellings that are not able to } \\
\text { keep out tidal floods or local floods because } \\
\text { of failure to raise the floor. }\end{array}$ \\
\hline $\begin{array}{l}\text { (13) Percentage of households } \\
\text { that do not have access to } \\
\text { sanitation }\end{array}$ & percent & $\begin{array}{l}\text { Percentage of households that do not have } \\
\text { access to sanitation in their building. }\end{array}$ \\
\hline \multicolumn{3}{|c|}{ Natural disaster and climate variability } \\
\hline $\begin{array}{l}{ }^{(14)} \text { Average number of disaster } \\
\text { events }\end{array}$ & $\begin{array}{l}\text { total number } \\
\text { of events }\end{array}$ & $\begin{array}{l}\text { Average number of disaster events, such as } \\
\text { tidal flood and local flood, in the last three } \\
\text { years. }\end{array}$ \\
\hline $\begin{array}{l}\text { (15) Percentage of households } \\
\text { that lost their physical assets } \\
\text { because of flood or tidal } \\
\text { flood }\end{array}$ & percent & $\begin{array}{l}\text { Percentage of households that lost their } \\
\text { physical assets because of natural disasters } \\
\text { and climate variability to an extent that their } \\
\text { livelihood strategies are impacted. }\end{array}$ \\
\hline $\begin{array}{l}\text { (16) Average distance to the } \\
\text { coastline }\end{array}$ & $\begin{array}{l}\text { distance } \\
(\mathrm{km})\end{array}$ & $\begin{array}{l}\text { Average distance to the coastline. The closer } \\
\text { the coastline, the higher the risk of tidal } \\
\text { flooding. }\end{array}$ \\
\hline $\begin{array}{l}\text { (17) Average distance to the } \\
\text { nearest river }\end{array}$ & $\begin{array}{l}\text { distance } \\
(\mathrm{km})\end{array}$ & $\begin{array}{l}\text { Average distance to the nearest river. The } \\
\text { closer the river, the higher the risk of local } \\
\text { flooding because of river overflow. }\end{array}$ \\
\hline
\end{tabular}

Sources: (Ahsan \& Warner, 2014; Donohue \& Biggs, 2015; Fang et al., 2014; Hahn, Riederer, \& Foster, 2009; Liu \& Liu, 2016; Morzaria-Luna, Turk-Boyer, \& MorenoBaez, 2014; Shah et al., 2013) 
In the LVI model, all components are considered equal in weight (Hahn, Riederer, \& Foster, 2009). Each component makes an equal contribution to the index ( Shah et al., 2013). Five steps were applied, as follows:

1. Transforming raw data into an appropriate measuring unit.

2. Standardization of each sub-component adopted from the Human Development Index calculation (United Nations Development Programme (UNDP), 2007):

index $=\frac{\text { actual value }- \text { min. value }}{\text { max. value }- \text { min. value }}$

3. After each sub-component was standardized, the sub-components were averaged to obtain the value of each main component. The scores of each main component were calculated as follows:

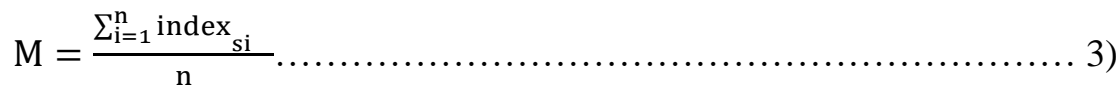

$M$ is one of the seven main components, which is the vulnerability score for each component; the index si represents the sub-components indexed by $i$ that make up each main component; and $n$ is the number of sub-components in each main component.

4. The LVI results for each component were ranged into a scale from 0 (least vulnerable) to 0.42 (most vulnerable). These values are the maximum and minimum values of each main component in the LVI model.

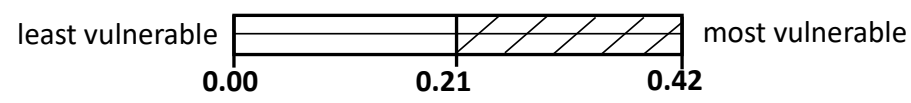

5. The overall LVI score was calculated as the average score of the seven components. These values are the maximum and minimum values of each main component in the LVI model.

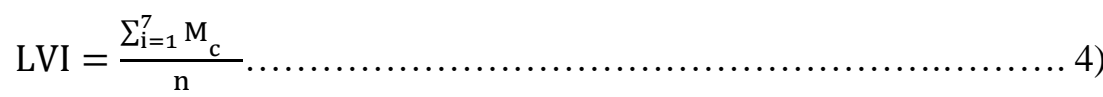

$L V I$ is the vulnerability index, which is the average of the seven main components; $M_{c}$ is the score of each main component derived from the subcomponents; and $n$ is the number of components.

\subsection{Assessing the LVI-IPCC}

According to the Intergovernmental Panel on Climate Change (2007), vulnerability is defined as a function of exposure, sensitivity to climate change and adaptive capacity (i.e. the ability of a system to cope with climate change impacts). The model developed by the IPCC uses the same data as the LVI model, but the LVI's seven main components are categorized into three vulnerability groups, as shown in Table 2.

The value of each vulnerability component is derived from the average value of the main components. The utilization of that value continues in the

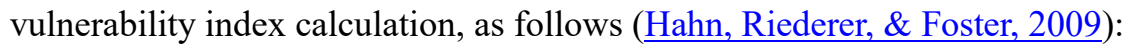

$$
\text { LVI-IPCCd }=(\mathrm{ed}-\mathrm{ad}) * \mathrm{sd}
$$

The $L V I-I P C C d$ equation expresses a vulnerability index for a community in district $d$; $e d$ is defined as the exposure value of a community in district $d$ (derived 
from the value of natural disaster and climate variability); $a d$ is defined as adaptive capacity value (derived from the average value of socio-demographic profiles, livelihood strategies and social networks values); and $s d$ is defined as a sensitivity value (sum of the average value of health, water resources and housing values). The IPCC model is scaled from -1 (least vulnerable) to +1 (most vulnerable).

Table 2. Mapping of LVI main components to the IPCC model

\begin{tabular}{l|l}
\hline IPCC vulnerability components & LVI main components \\
\hline Adaptive capacity & Socio-demographic profiles \\
& Livelihood strategies \\
& Social networks \\
\hline Sensitivity & Health \\
& Water resources \\
\hline Exposure & Housing \\
\hline & Natural disaster and climate variability \\
\hline
\end{tabular}

\section{RESULTS AND DISCUSSION}

\subsection{Spatial Exposure}

Based on Central Bureau Statistic (CBS) (2014), about 32.20\% of West Tegal sub-district communities work as fishermen. However, Tegal's coastal area is affected by climate-related disasters such as floods and tidal floods. According to previous research by Zulaykha, Subardjo, and Atmodjo (2015), land for housing and fishery in Tegal's coastal area is vulnerable to tidal floods. As shown in Figure 4, most of the coastal areas in the study area (Muarareja and Tegalsari) are vulnerable to tidal floods and others to local floods. The figure also shows that most of the residential areas (depicted in yellow) are vulnerable to tidal floods because they are within 1-2 km of the coastline. Improving the house structure is a common remedy in this area as it may prevent water from entering the house. The unsuitable drainage system in the study area worsens its exposure in terms of health and environmental issues.

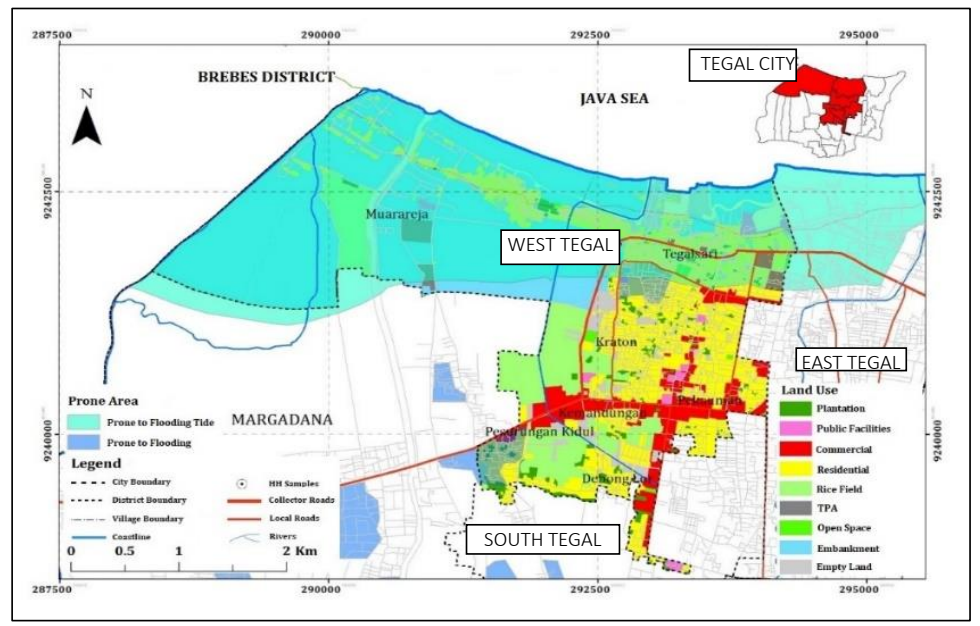

Figure 4. Land use and hazards map

Concerning exposure to climate-related disaster events, either tidal floods or floods, the study area was classified into three groups based on the frequency of events occurring there per year: less than three events, three to five events and more than five events, as shown in Figure 5. The spatial distribution of disaster events was derived from the interpolation of household samples. The area with 
the most frequent events (more than five events) was close to the coastline. Most of the households in Muarareja and Tegalsari were exposed to tidal floods. The highest level of tidal flooding in these two kelurahan was commonly found in the rainy season, when the tidal wave is high. In kelurahan Kraton and Pekauman, disaster events were found to occur about three to five times, and less than three times in parts of kelurahan Pekauman. Fewer disaster events were discovered in other kelurahan areas such as Kemandungan, Pasurungan Kidul and Debong, each of which experienced less than three events per year. This shows that the closer the area to the coastline, the higher the level of exposure to climate-related disasters. Therefore, a greater effort needs to be made in certain areas.

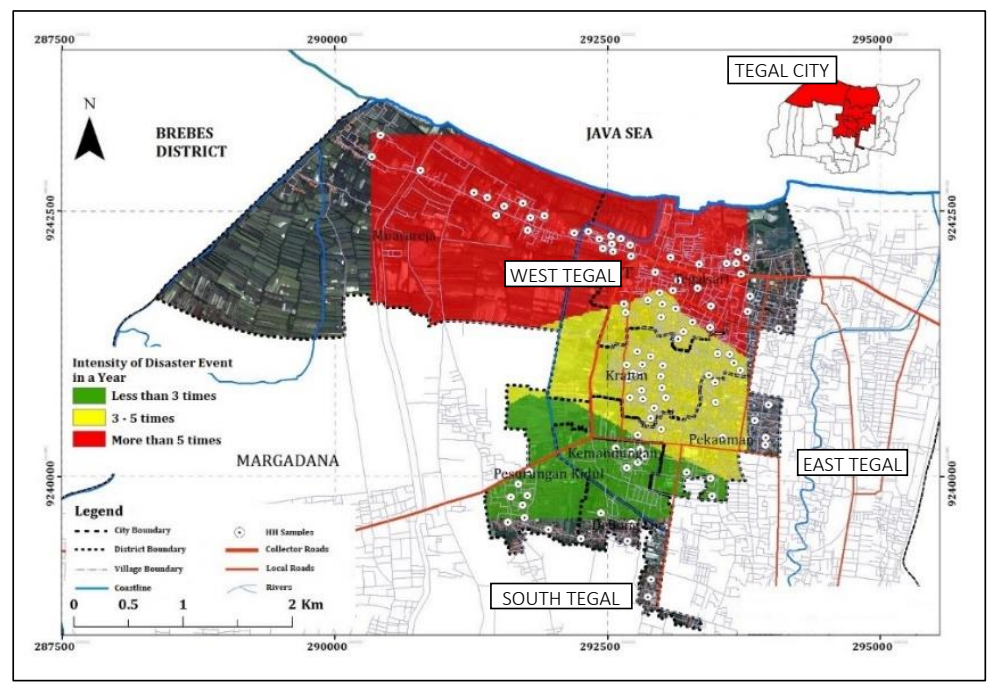

Figure 5. Intensity of disaster events

Exposure to floods and tidal floods is dependent on the location of each household relative to the coastline as well as to rivers. Based on the distributed household samples, the average distance of households to the coastline was 1.48 $\mathrm{km}$, with the largest distance being $3.65 \mathrm{~km}$ and the smallest $0.32 \mathrm{~km}$. The average distance to a river was found to be about $0.59 \mathrm{~km}$, with $1.06 \mathrm{~km}$ being the farthest and $0.05 \mathrm{~km}$ the nearest.

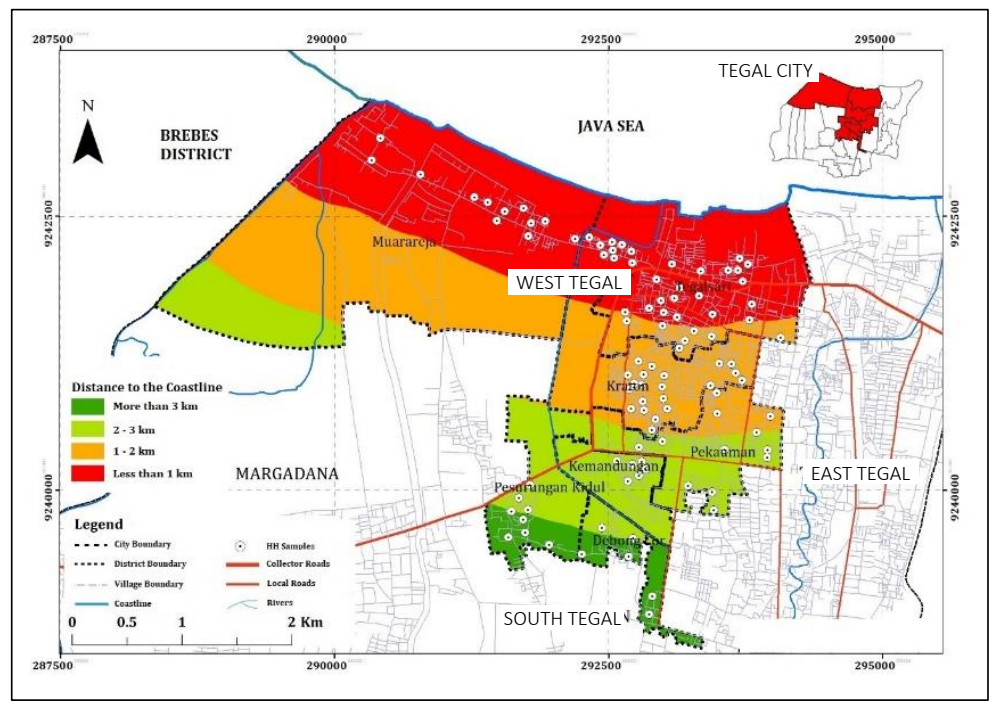

Figure 6. Distance to the coastline

As shown in and Figure $7 a$, distance to the coastline was grouped into four classes: less than $1 \mathrm{~km}, 1-2 \mathrm{~km}, 2-3 \mathrm{~km}$ and more than $3 \mathrm{~km}$. The intention in creating those classes is to show the exposure probability that the distributed household samples would experience the impacts of climate-related disasters like 
tidal floods. The figure also shows that both kelurahan Muarareja and Tegalsari contain areas that are less than $1 \mathrm{~km}$ from the coastline. With the relatively close distance to the coastline, all the households located within this area are exposed to tidal floods. As shown in Figure 7a, the area closest to the coast had the largest number of household samples.

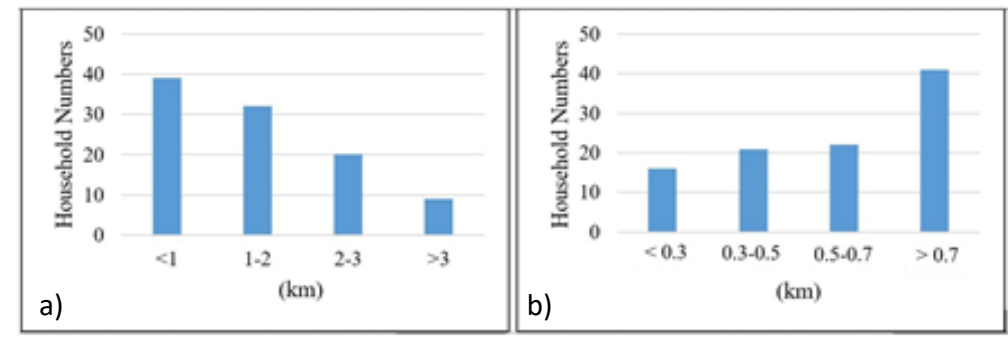

Figure 7. (a) Distances to the coastline and (b) Distances to a river

There are two major rivers in the study area: one in West Tegal sub-district and the other in East Tegal sub-district (see Figure 8). Distance to the river is grouped into four classes: less than $0.3 \mathrm{~km}, 0.3-0.5 \mathrm{~km}, 0.5-0.7 \mathrm{~km}$ and more than $0.7 \mathrm{~km}$. The exposure of households to the impacts of floods from the river is greater for households located close to a river. Most of the household samples in the study area are located more than $0.7 \mathrm{~km}$ from either river. In kelurahan Tegalsari, however, most of the household samples are situated within $0.3 \mathrm{~km}$ of the river and are therefore more vulnerable.

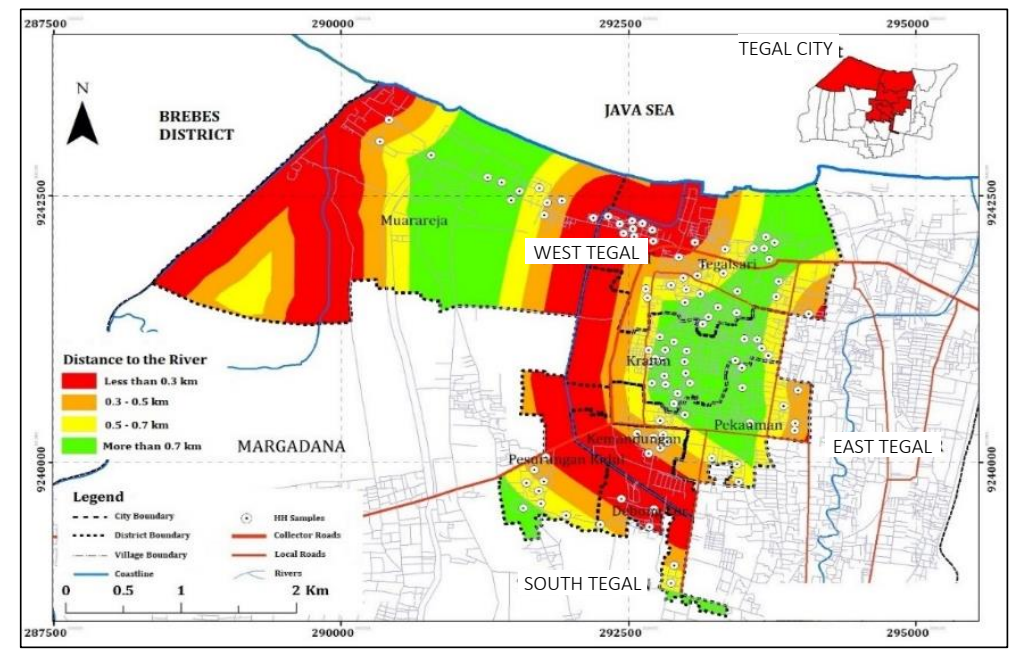

Figure 8. Distance to rivers

The existence of households living close to the coastline as well as a river contributes to a higher level of vulnerability since the area would be a frontline area for both floods and tidal floods (Barbier, 2015; Can, Tu, \& Hoanh, 2013). According to (Badan Perencanaan Pembangunan Penelitian dan Pengembangan Daerah (BP4D), 2017), among the four sub-districts in Tegal, West Tegal has the second-highest flood risk. Annually, the duration of tidal floods, which affect 90 ha of West Tegal, is equal to three days. The frequency is approximately five times a year; the depth is $0.2-0.6 \mathrm{~m}$ on average. As shown in Table 3, kelurahan Tegalsari experiences the worst flooding, with total area of 11.01 ha affected, followed by kelurahan Pesurungan Kidul $(9.61 \mathrm{ha})$. The surface area that is flooded in these two kelurahan is significantly greater than in the other five kelurahan in West Tegal, where less than 3 ha are typically flooded. 
Table 3. Flooded areas and drainage conditions

\begin{tabular}{lrrrrr}
\hline $\begin{array}{c}\text { Urban } \\
\text { village/kelurahan }\end{array}$ & $\begin{array}{c}\text { Flooded } \\
\text { area (ha) }\end{array}$ & $\begin{array}{c}\text { Flooded } \\
\text { area } \\
(\%)\end{array}$ & $\begin{array}{c}\text { Total } \\
\text { drainage } \\
\text { length (m) }\end{array}$ & $\begin{array}{c}\text { Drainage } \\
\text { length in } \\
\text { settlement } \\
\text { areas (m) }\end{array}$ & $\begin{array}{c}\text { Drainage in } \\
\text { settlement } \\
\text { areas (\%) }\end{array}$ \\
\hline Pesurungan Kidul & 9.61 & 34.07 & 13,124 & 5,396 & 41.12 \\
Debong Lor & 2.60 & 9.21 & 5,244 & 4,137 & 78.89 \\
Kemandungan & 1.17 & 4.15 & 6,516 & 5,238 & 80.39 \\
Pekauman & 0.49 & 1.75 & 15,852 & 12,929 & 81.56 \\
Kraton & 2.08 & 7.37 & 16,314 & 12,928 & 79.24 \\
Tegalsari & 11.01 & 39.03 & 30,454 & 17,894 & 58.76 \\
Muarareja & 1.37 & 4.87 & 7,818 & 4,333 & 55.42 \\
\hline
\end{tabular}

Source: $B 4 P D, 2017$

In terms of the availability of drainage infrastructure, the kelurahan in West Tegal that have a lower risk of floods and tidal floods generally have a greater portion of their system in settlement areas. Kelurahan Pekauman, which has an extensive drainage system in its settlement areas, also has the smallest area (0.49 ha) affected by floods. It shows that the availability of drainage infrastructure can significantly reduce the risk of flooding in affected areas. As shown by (Rudiarto et al., 2018) and Handayani et al. (2017), most of the settlement areas on the north coast of Central Java, including Tegal, have poor infrastructure. Due to their devastating impact on Tegal, floods have become a key issue, so the local government has been allocating more than $70 \%$ of the local budget to irrigation and flood control measures such as polders, pool retention, dike construction, river normalization, seawall development and drainage improvement and maintenance (Handayani et al., 2019). Better land use planning to control development is also an important strategy to mitigate disaster risk, as well as the implementation of early warning systems to improve disaster awareness. Land use planning is useful to identify disaster-prone areas so that future development projects can be located in less vulnerable areas.

\subsection{Livelihood Vulnerability Assessment}

The standardized values of each sub-component produce the value of each main component in the LVI model, as shown in Table 4. Socio-demographic profiles in the West Tegal sub-district have a value of 0.31 , with the greatest contribution coming from the average number of family members, with a value of 0.50. Tizale (2007) explains that many family members can raise the opportunity of other family members to support family incomes, both from primary sectors in their community and others. The dependency ratio and percentage of households where the head of the household has not attended primary school have values of 0.25 and 0.19 , respectively. The dependency ratio compares the number of family members who are of non-productive age with those of productive age. Productive-age members of a family have a duty to support the non-productive ones. When the head of a household has not attended primary school, the family is less adaptive to climate change impacts because of limited knowledge.

Household livelihood strategies in West Tegal have a value of 0.30 , the highest contributor being the percentage of households that have saving ability, with a value of 0.37 . The percentage of households that have the ability to save explains how many households have financial adaptive capacity. The proportion of households that depend on the coastal sector for their income is 0.29 , and the proportion of households that have livelihood alternatives is 0.25 . Most of the inhabitants in the study area depend on available local support resources, so the 
disturbance of these resources directly influences income generation (Rudiarto, Rahmawati, \& Sejati, 2020) and consequently threatens saving ability.

In terms of social networks, the LVI index shows a value of 0.1 . The value represents the percentage of households that asked for help from their neighbourhood or local government in the last 12 months. The number of neighbourhoods that are still able to provide help to their inhabitants shows the existence of social networks that contribute to adaptive capacity.

The health main component has a value of 0.37 , its highest contribution coming from the average time needed to reach a health facility. The average travel time to a health facility explains whether the distribution of health facilities in West Tegal sub-district is equal or not, while health insurance captures the availability of health services during times when the community is exposed to climate-related disasters.

Table 4. Calculation of livelihood vulnerability index

\begin{tabular}{|c|c|c|c|c|c|c|c|}
\hline Sub-component & Unit & $\begin{array}{l}\text { Actual } \\
\text { value }\end{array}$ & Max. & Min. & $\begin{array}{l}\text { Standardi } \\
\text { zation }\end{array}$ & $\begin{array}{l}\text { Main } \\
\text { component }\end{array}$ & $\begin{array}{l}\text { Compone } \\
\text { nt value }\end{array}$ \\
\hline Dependency ratio & ratio & 0.38 & 1.50 & 0.00 & 0.25 & \multirow{3}{*}{$\begin{array}{l}\text { Socio- } \\
\text { demographic } \\
\text { profiles }\end{array}$} & \multirow[t]{3}{*}{0.31} \\
\hline $\begin{array}{l}\text { Percentage of households } \\
\text { where the head of the } \\
\text { household did not attend } \\
\text { school }\end{array}$ & $\%$ & 19.00 & 100.00 & 0.00 & 0.19 & & \\
\hline $\begin{array}{lll}\text { Average number } & \text { of } \\
\text { family members } & \text { in } \\
\text { household } & & \\
\end{array}$ & $\begin{array}{l}\text { number } \\
\text { of } \\
\text { persons }\end{array}$ & 5.00 & 8.00 & 2.00 & 0.50 & & \\
\hline $\begin{array}{l}\text { Percentage of households } \\
\text { that depend on the coastal } \\
\text { sector for their income }\end{array}$ & $\%$ & 29.00 & 100.00 & 0.00 & 0.29 & \multirow[t]{3}{*}{$\begin{array}{l}\text { Livelihood } \\
\text { strategies }\end{array}$} & \multirow[t]{3}{*}{0.30} \\
\hline $\begin{array}{l}\text { Percentage of households } \\
\text { that have livelihood } \\
\text { alternatives }\end{array}$ & $\%$ & 25.00 & 100.00 & 0.00 & 0.25 & & \\
\hline $\begin{array}{l}\text { Percentage of households } \\
\text { that have saving ability }\end{array}$ & $\%$ & 37.00 & 100.00 & 0.00 & 0.37 & & \\
\hline $\begin{array}{l}\text { Percentage of households } \\
\text { who asked for help from } \\
\text { their neighbourhood or } \\
\text { local government in the } \\
\text { previous } 12 \text { months }\end{array}$ & $\%$ & 10.00 & 100.00 & 0.00 & 0.10 & $\begin{array}{l}\text { Social } \\
\text { networks }\end{array}$ & 0.10 \\
\hline $\begin{array}{l}\text { Average time needed to } \\
\text { reach a health facility }\end{array}$ & minutes & 7.98 & 10.00 & 5.00 & 0.60 & \multirow[t]{2}{*}{ Health } & \multirow[t]{2}{*}{0.37} \\
\hline $\begin{array}{l}\text { Percentage of households } \\
\text { that do not have health } \\
\text { insurance }\end{array}$ & $\%$ & 15.00 & 100.00 & 0.00 & 0.15 & & \\
\hline $\begin{array}{l}\text { Percentage of households } \\
\text { that use natural water } \\
\text { resources }\end{array}$ & $\%$ & 42.00 & 100.00 & 0.00 & 0.42 & $\begin{array}{l}\text { Water } \\
\text { resources }\end{array}$ & 0.42 \\
\hline $\begin{array}{l}\text { Percentage of housing } \\
\text { that are vulnerable to } \\
\text { disasters }\end{array}$ & $\%$ & 18.00 & 100.00 & 0.00 & 0.18 & \multirow[t]{3}{*}{ Housing } & \multirow[t]{3}{*}{0.18} \\
\hline $\begin{array}{l}\text { Percentage of homes that } \\
\text { did not raise their floor to } \\
\text { prevent flood hazard }\end{array}$ & $\%$ & 15.00 & 100.00 & 0.00 & 0.15 & & \\
\hline $\begin{array}{l}\text { Percentage of households } \\
\text { that do not have access to } \\
\text { sanitation }\end{array}$ & $\%$ & 20.00 & 100.00 & 0.00 & 0.20 & & \\
\hline $\begin{array}{l}\text { Average number of } \\
\text { disaster events }\end{array}$ & $\begin{array}{c}\text { Total } \\
\text { events }\end{array}$ & 5.54 & 7.00 & 3.00 & 0.63 & \multirow{4}{*}{$\begin{array}{l}\text { Natural } \\
\text { disaster and } \\
\text { climate } \\
\text { variability }\end{array}$} & \multirow[t]{4}{*}{0.41} \\
\hline $\begin{array}{l}\text { Percentage of households } \\
\text { that lost their physical } \\
\text { assets because of flood or } \\
\text { tidal flood }\end{array}$ & $\%$ & 10.00 & 100.00 & 0.00 & 0.10 & & \\
\hline $\begin{array}{l}\text { Average distance to the } \\
\text { coastline }\end{array}$ & $\mathrm{km}$ & 1.48 & 3.65 & 0.32 & 0.32 & & \\
\hline $\begin{array}{l}\text { Average distance to the } \\
\text { nearest river }\end{array}$ & $\mathrm{km}$ & 0.59 & 1.06 & 0.05 & 0.54 & & \\
\hline
\end{tabular}

Note: The vulnerability index value from the LVI model is 0.29, which implies vulnerability to climate change. The LVI is scaled from 0 (least vulnerable) to 0.5 (most vulnerable).

The water resources component explains how households in West Tegal meet their needs for clean water. It has a value of 0.42 , indicating that some households 
still use natural water resources. It has a greater sensitivity level because natural water resources such as wells, rain and rivers are exposed to pollutants from climate-related disasters and therefore may have lower water quality.

The housing main component has a moderate value of about 0.18 , with the greatest contribution coming from the percentage of households that do not have access to sanitation, followed by the percentage of households impacted by floods and tidal floods and households with a raised floor. Households with no access to sanitation in their building have a greater sensitivity to climate change, so increasing access to sanitation is an important strategy for climate change adaptation (McGranahan, Balk, \& Anderson, 2007). Similarly, Kundzewicz et al. (2008) state that adaptation to climate change must consider factors not related to climate change that can remove pollutants from water resources, such as adequate sanitation.

Natural disaster and climate variability explains how great is the stress of climate-related disasters on West Tegal's environment. The value of this main component is 0.41 . The average number of disaster events makes the largest contribution, with a value of 0.63 . It shows that the West Tegal sub-district is highly exposed to the impacts of climate-related disasters. Households' distance to the coastline or a river can raise the district's exposure level. Proximity to a coastline can raise exposure to tidal floods, while proximity to a river raises exposure to local floods due of river overflow.

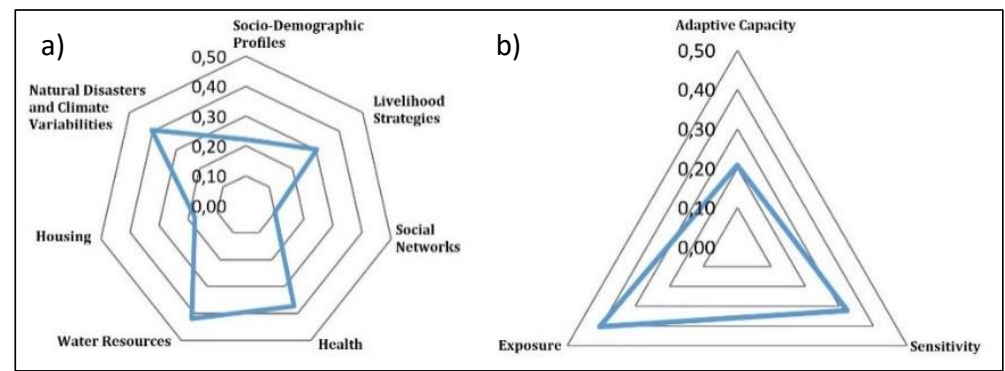

Figure 9. Vulnerability spider diagram for the LVI (a) and LVI-IPCC (b) models

In the last analysis performed in this study, the components of the previously calculated LVI were assessed and grouped into three main categories of vulnerability (adaptive capacity, sensitivity and exposure), which were then turned into a spider diagram that describes the vulnerability level of each component. The spider diagram for the main components of the LVI model is presented in Figure 9a, which shows the contribution of each main component to the livelihood system vulnerability. As can be seen in the figure, the main component that makes the largest contribution to the vulnerability index is natural disaster and climate vulnerability. It explains that the West Tegal sub-district, as a coastal area, is vulnerable to climate-related disaster variability. Similarly, Barbier (2015) stated that coastal areas everywhere are on the front lines of climate change exposure and their communities are vulnerable, especially poor ones. The main component with the smallest contribution is social networks, however other research has shown these are known to play an important role in developing social resilience (Adger, W. Neil et al., 2005).

In the assessment of LVI combined with the IPCC model, three major components were included. As shown in Figure $9 b$ and Table 5, exposure level makes the greatest contribution to the index in the joint LVI-IPCC model. The LVI-IPCC calculation result shows that the coastal community livelihood system in the West Tegal sub-district is vulnerable to climate-related disasters. Based on the value of the vulnerability index in both the LVI and the LVI-IPCC models, the West Tegal sub-district is categorized as highly vulnerable. In the LVI model, 
the value of the vulnerability index is about 0.29 , which is in the most vulnerable category. Similarly, the calculation using the LVI-IPCC model yields a value of about 0.06 , closer to +1 than -1 , making the study area vulnerable. However, despite its advantages in data and value flexibility, the LVI method mostly captures local conditions and may not be suitable for other populations (Hahn, Riederer, \& Foster, 2009). An adjustment to local conditions is needed to determine the sub-components which may enrich the more adaptable method, as LVI and LVI-IPCC are locally specific.

Table 5. Calculation result of the LVI-IPCC model

\begin{tabular}{ll}
\hline Vulnerability component & Value \\
\hline Adaptive capacity & 0.24 \\
Sensitivity & 0.32 \\
Exposure & 0.41 \\
LVI-IPCC & 0.06 \\
\hline
\end{tabular}

Note: The vulnerability index value of the LVI-IPCC model is 0.06, which is in a vulnerable category. The LVI-IPCC model is scaled between -1 (least vulnerable) to +1 (most vulnerable).

This study confirms that the livelihood system in the West Tegal sub-district is vulnerable because of a low capacity to adapt at the household level, hence it cannot cope with exposure to disasters such as tidal floods and floods. Similarly, Handayani et al. (2017) found that vulnerability in a small city was due to its lack of adaptive capacity rather than exposure or sensitivity. Our results are also in line with the research done by Buchori et al. (2018) and (Rudiarto et al., 2020), which indicated that structural adaptive capacity is a crucial factor in reducing vulnerability in the coastal areas of Semarang, Central Java. Huoang et al. (2018) showed that lower adaptive capacity and sensitivity resulted in high exposure in Hien Long commune, which also raised its vulnerability level compared to two other communes in Northwest Vietnam. Lack of adaptive capacity was found as the major contributor to vulnerability in some parts of rural Nepal (Pandey \& Bardsley, 2015; Panthi et al., 2016). Lower adaptive capacity is believed to be the principal cause of vulnerability, particularly in developing countries (Füssel, 2010). Furthermore, according to Wisner et al. (2004), the main issue with vulnerability is not the hazard but rather critical livelihood conditions that affect the ability of a person or community to respond to a hazardous occurrence. However, despite the predominance of adaptive capacity found in this study, exposure and sensitivity remain important contributors to vulnerability.

It is clear that the level of vulnerability is significantly related to the subcomponents or indicators chosen in the primary survey (Hahn, Riederer, \& Foster, 2009). In this study, we used the sub-components that are directly associated with the livelihood values and assets of the households sampled with regard to floods and tidal floods. Therefore, the diversification of livelihoods would substantially improve the community's adaptive capacity and reduce its vulnerability. As the livelihood system is tied to small-scale economics, establishment of a livelihood framework is crucial to shape a more applicable indicator system in vulnerability assessments. This suggests that a more local framework of essential liabilities should be created for the human-environment relationship, including biophysical and social environments (Dolan \& Walker, 2006), which can be derived specifically from the understanding of how the coastal community is affected based on its vulnerability. The involvement of the coastal community in a selfassessment, where the residents can determine which factors are more closely linked to their livelihood vulnerability, would make the assessment more accurate. This is also a suitable approach to encourage the community's engagement in understanding their living environment. 


\section{CONCLUSION}

The high level of livelihood vulnerability found in the study area is driven especially by natural disaster and climate variability. This indicates that households are prone to climate-related disaster variability, which may also impact their quality of life. Assessment of the coastal households in the West Tegal sub-district using both LVI and LVI-IPCC models place the sub-district within their most vulnerable level. The sub-district has a high level of exposure and sensitivity to climate-related disasters and a low level of adaptive capacity. The coastal community can barely cope with climate change impacts such as tidal floods and floods. This suggests the need for a more adaptive livelihood system. The coastal community in West Tegal sub district could raise their adaptive capacity by developing their social networks. This can be achieved by developing networks such as a fishermen's communities. Through such a community, livelihood alternatives and social insurance could be enhanced. Building communal infrastructure can improve access to sanitation, whilst local governments can develop adaptive capacity by building preventive infrastructure, such as tidal breakwaters and river dikes. It is also important to avoid land use conversion in coastal areas to prevent serious environmental degradation.

The application of the LVI and LVI-IPCC models is useful in understanding the components and sub-components of vulnerability. It shows how socioeconomic and physical environments can shape vulnerability at the local level, where more or less vulnerable components can be directly identified. This study can also be used by practitioners, researchers, local governments and other stakeholders to choose the right interventions. Despite its usefulness, however, this study constitutes a locally-based approach in which the selection of suitable indicators is especially important. Therefore, designing the indicators of each component requires extensive gathering of information from different sources, including a literature review, reputable experts and the community itself. Moreover, this study analysed only one community, but it would be beneficial to conduct this type of research on multiple communities to compare vulnerability levels among them.

This study conducted the assessment at both regional and local levels with different emphases. The purpose of covering both levels is to highlight the fact that an assessment at the local level is not possible without also understanding spatial conditions at the regional level. Even though the emphasis of each assessment is different, they complement each other. The spatial assessment on a regional scale reveals the distribution and grade of vulnerable areas, providing research background on the local-level assessment. The local-level assessment shows the people's vulnerability, thus improving the regional vulnerability assessment. Furthermore, the combination of regional and local assessments presents a great opportunity for future research to describe livelihood vulnerability conditions in a way that is more spatially comparable.

\section{ACKNOWLEDGMENT}

This research was funded by the Directorate of Research and Community Services - Directorate General of Higher Education, Ministry of Research and Technology. We would like to thank the Government of Tegal City for the data and shared information provided during the survey period. Greatly thank all reviewers for the valuable comments and remarks during the review process. 


\section{REFERENCES}

Adger, W. N. (2006). "Vulnerability". Global Environmental Change, 16(3), 268-281. doi: https://doi.org/10.1016/j.gloenvcha.2006.02.006.

Adger, W. N., Agrawal, S., Mirza, M., Conde, C., O'brien, K., Pulhin, J., . . Takahashi, K. (2007). "Assessment of Adaptation Practices, Options, Constraints and Capacity". Climate Change 2007: Impacts, Adaptation and Vulnerability. Contribution of Working Group Ii to the Fourth Assessment Report of the Intergovernmental Panel on Climate Change (pp. 719743). Cambridge: Cambridge University Press.

Adger, W. N., Hughes, T. P., Folke, C., Carpenter, S. R., \& Rockström, J. (2005). "SocialEcological Resilience to Coastal Disasters". Science, 309(5737), 1036-1039. doi: https://doi.org/10.1126/science.1112122.

Ahsan, M. N., \& Warner, J. (2014). "The Socioeconomic Vulnerability Index: A Pragmatic Approach for Assessing Climate Change Led Risks-a Case Study in the South-Western Coastal Bangladesh". International Journal of Disaster Risk Reduction, 8, 32-49. doi: https://doi.org/10.1016/j.ijdrr.2013.12.009.

Allison, E. H., \& Ellis, F. (2001). "The Livelihoods Approach and Management of Small-Scale Fisheries". Marine policy, 25(5), 377-388. doi: https://doi.org/10.1016/S0308597X(01)00023-9.

Allison, E. H., Perry, A. L., Badjeck, M.-C., Neil Adger, W., Brown, K., Conway, D., . . Dulvy, N. K. (2009). "Vulnerability of National Economies to the Impacts of Climate Change on Fisheries". Fish and Fisheries, 10(2), 173-196. doi: https://doi.org/10.1111/j.14672979.2008.00310.x.

Badan Nasional Penanggulangan Bencana (BNPB). (2012). "Pedoman Umum Pengkajian Risiko Bencana". Peraturan Kepala, 2.

Badan Perencanaan Pembangunan Penelitian dan Pengembangan Daerah (BP4D). (2017) Rencana Aksi Daerah Air Minum Dan Penyehatan Lingkungan (Rad Ampl) Kota Tegal 2017-2021. Tegal: BP4D.

Barbier, E. B. (2015). "Climate Change Impacts on Rural Poverty in Low-Elevation Coastal zones". Estuarine, Coastal and Shelf Science, 165, A1-A13. doi: https://doi.org/10.1016/i.ecss.2015.05.035.

Bjarnadottir, S., Li, Y., \& Stewart, M. G. (2011). "Social Vulnerability Index for Coastal Communities at Risk to Hurricane Hazard and a Changing Climate". Natural Hazards, 59(2), 1055-1075. doi: https://doi.org/10.1007/s11069-011-9817-5.

Bosello, F., \& De Cian, E. (2014). "Climate Change, Sea Level Rise, and Coastal Disasters. A Review of Modeling Practices". Energy Economics, 46, 593-605. doi: https://doi.org/10.1016/j.eneco.2013.09.002.

Buchori, I., Pramitasari, A., Sugiri, A., Maryono, M., Basuki, Y., \& Sejati, A. W. (2018) "Adaptation to Coastal Flooding and Inundation: Mitigations and Migration Pattern in Semarang City, Indonesia". Ocean \& Coastal Management, 163, 445-455. doi: https://doi.org/10.1016/j.ocecoaman.2018.07.017.

Buotte, P. C., Peterson, D. L., McKelvey, K. S., \& Hicke, J. A. (2016). "Capturing Subregional Variability in Regional-Scale Climate Change Vulnerability Assessments of Natural Resources". Journal of environmental management, 169, 313-318. doi: https://doi.org/10.1016/j.jenvman.2015.12.017.

Can, N. D., Tu, V. H., \& Hoanh, C. T. (2013). "Application of Livelihood Vulnerability Index to Assess Risks from Flood Vulnerability and Climate Variability: A Case Study in the Mekong Delta of Vietnam". Journal of Environmental Science and Engineering, 2(8), 476486.

Central Bureau Statistic (CBS). (2014). Kota Tegal Dalam Angka 2014. Tegal: Central Bureau Statistic.

Cutter, S. L., Boruff, B. J., \& Shirley, W. L. (2003). "Social Vulnerability to Environmental Hazards*". Social Science Quarterly, 84(2), 242-261. doi: https://doi.org/10.1111/15406237.8402002 .

Daramola, A. Y., Oni, O. T., Ogundele, O., \& Adesanya, A. (2016). "Adaptive Capacity and Coping Response Strategies to Natural Disasters: A Study in Nigeria". International Journal of Disaster Risk Reduction, 15, 132-147. doi: https://doi.org/10.1016/j.ijdrr.2016.01.007.

De Sherbinin, A., Chai-Onn, T., Jaiteh, M., Mara, V., Pistolesi, L., Schnarr, E., \& Trzaska, S. (2015). "Data Integration for Climate Vulnerability Mapping in West Africa". ISPRS International Journal of Geo-Information, 4(4), 2561-2582. doi: https://doi.org/10.3390/ijgi4042561.

Dolan, A. H., \& Walker, I. J. (2006). "Understanding Vulnerability of Coastal Communities to Climate Change Related Risks". Journal of Coastal Research, Special Issue No. 39. 
Proceedings of the 8th International Coastal Symposium (ICS 2004), Vol. III (Winter 2006), 1316-1323.

Donohue, C., \& Biggs, E. (2015). "Monitoring Socio-Environmental Change for Sustainable Development: Developing a Multidimensional Livelihoods Index (Mli)". Applied geography, 62, 391-403. doi: https://doi.org/10.1016/j.apgeog.2015.05.006.

Dulal, H. B., Brodnig, G., Thakur, H. K., \& Green-Onoriose, C. (2010). "Do the Poor Have What They Need to Adapt to Climate Change? A Case Study of Nepal". Local Environment, 15(7), 621-635. doi: https://doi.org/10.1080/13549839.2010.498814.

Eakin, H., \& Luers, A. L. (2006). "Assessing the Vulnerability of Social-Environmental Systems". Annual Review of Environment and Resources, 31, 365-394. doi: https://doi.org/10.1146/annurev.energy.30.050504.144352.

Ebi, K. L., Kovats, R. S., \& Menne, B. (2006). "An Approach for Assessing Human Health Vulnerability and Public Health Interventions to Adapt to Climate Change". Environmental Health Perspectives, 114(12), 1930-1934. doi: https://doi.org/10.1289/ehp.8430.

Ellis, F. (2000). Rural Livelihoods and Diversity in Developing Countries. Oxford university press.

Eriksen, S. H., \& Kelly, P. M. (2007). "Developing Credible Vulnerability Indicators for Climate Adaptation Policy Assessment". Mitigation and Adaptation Strategies for Global Change, 12(4), 495-524. doi: https://doi.org/10.1007/s11027-006-3460-6.

Fakhruddin, S. H. M., \& Rahman, J. (2015). "Coping with Coastal Risk and Vulnerabilities in Bangladesh". International Journal of Disaster Risk Reduction, 12, 112-118. doi: https://doi.org/10.1016/j.ijdrr.2014.12.008.

Fang, Y.-p., Fan, J., Shen, M.-y., \& Song, M.-q. (2014). "Sensitivity of Livelihood Strategy to Livelihood Capital in Mountain Areas: Empirical Analysis Based on Different Settlements in the Upper Reaches of the Minjiang River, China". Ecological Indicators, 38, 225-235. doi: https://doi.org/10.1016/j.ecolind.2013.11.007.

Ferrol-Schulte, D., Gorris, P., Baitoningsih, W., Adhuri, D. S., \& Ferse, S. C. A. (2015). "Coastal Livelihood Vulnerability to Marine Resource Degradation: A Review of the Indonesian National Coastal and Marine Policy Framework". Marine policy, 52, 163-171. doi: https://doi.org/10.1016/j.marpol.2014.09.026.

Flanagan, B. E., Gregory, E. W., Hallisey, E. J., Heitgerd, J. L., \& Lewis, B. (2011). "A Social Vulnerability Index for Disaster Management". Journal of Homeland Security and Emergency Management, 8(1), 0000102202154773551792. doi: https://doi.org/10.2202/1547-7355.1792.

Ford, J. D., \& Smit, B. (2004). "A Framework for Assessing the Vulnerability of Communities in the Canadian Arctic to Risks Associated with Climate Change". Arctic, 57(4), 389-400. doi: https://doi.org/10.14430/arctic516.

Füssel, H.-M. (2010). "How Inequitable Is the Global Distribution of Responsibility, Capability, and Vulnerability to Climate Change: A Comprehensive Indicator-Based Assessment". Global Environmental Change, 20(4), 597-611. doi: https://doi.org/10.1016/j.gloenvcha.2010.07.009.

Gao, X., Yuan, H., Qi, W., \& Liu, S. (2014). "Assessing the Social and Economic Vulnerability of Urban Areas to Disasters: A Case Study in Beijing, China". International Review for Spatial Planning and Sustainable Development, 2(1), 42-62. doi: https://doi.org/10.14246/irspsd.2.1 42.

Gibbes, C., Southworth, J., \& Keys, E. (2009). "Wetland Conservation: Change and Fragmentation in Trinidad's Protected Areas". Geoforum, 40(1), 91-104. doi: https://doi.org/10.1016/j.geoforum.2008.05.005.

Glavovic, B. C., \& Boonzaier, S. (2007). "Confronting Coastal Poverty: Building Sustainable Coastal Livelihoods in South Africa". Ocean \& Coastal Management, 50(1), 1-23. doi: https://doi.org/10.1016/j.ocecoaman.2006.07.001.

Glick, P., Stein, B. A., \& Edelson, N. A. (Eds.). (2011). Scanning the Conservation Horizon: A Guide to Climate Change Vulnerability Assessment. Washington, D.C: National Wildlife Federation. Retrieved https://repository.library.noaa.gov/view/noaa/10088/noaa 10088 DS1.pdf.

Hahn, M. B., Riederer, A. M., \& Foster, S. O. (2009). "The Livelihood Vulnerability Index: A Pragmatic Approach to Assessing Risks from Climate Variability and Change — a Case Study in Mozambique". Global Environmental Change, 19(1), 74-88. doi: https://doi.org/10.1016/j.gloenvcha.2008.11.002.

Handayani, W., Fisher, M. R., Rudiarto, I., Sih Setyono, J., \& Foley, D. (2019). "Operationalizing Resilience: A Content Analysis of Flood Disaster Planning in Two Coastal Cities in Central Java, Indonesia". International Journal of Disaster Risk Reduction, 35 , 101073. doi: https://doi.org/10.1016/j.ijdrr.2019.101073.

Handayani, W., Rudiarto, I., Setyono, J. S., Chigbu, U. E., \& Sukmawati, A. M. a. (2017). "Vulnerability Assessment: A Comparison of Three Different City Sizes in the Coastal Area of Central Java, Indonesia". Advances in Climate Change Research, 8(4), 286-296. doi: 
https://doi.org/10.1016/j.accre.2017.11.002.

Huong, N. T. L., Yao, S., \& Fahad, S. (2019). "Assessing Household Livelihood Vulnerability to Climate Change: The Case of Northwest Vietnam". Human and Ecological Risk Assessment: An International Journal, 25(5), 1157-1175. doi: https://doi.org/10.1080/10807039.2018.1460801.

Intergovernmental Panel on Climate Change. (2007). Climate Change 2007 - Mitigation of Climate Change: Working Group Iii Contribution to the Fourth Assessment Report of the Ipcc. Cambridge: Cambridge University Press. doi: http://dx.doi.org/10.1017/CBO9780511546013.

Intergovernmental Panel on Climate Change (IPCC). (2001). Climate Change 2001: Impacts, Adaptation, and Vulnerability: Contribution of Working Group Ii to the Third Assessment Report of the Intergovernmental Panel on Climate Change. (Vol. 2) Cambridge University Press.

Khayyati, M., \& Aazami, M. (2016). "Drought Impact Assessment on Rural Livelihood Systems in Iran". Ecological Indicators, 69, 850-858. doi: https://doi.org/10.1016/j.ecolind.2016.05.039.

Kumar, P., Geneletti, D., \& Nagendra, H. (2016). "Spatial Assessment of Climate Change Vulnerability at City Scale: A Study in Bangalore, India". Land Use Policy, 58, 514-532. doi: https://doi.org/10.1016/j.landusepol.2016.08.018.

Kundzewicz, Z. W., Mata, L. J., Arnell, N. W., DÖLl, P., Jimenez, B., Miller, K., . . . Shiklomanov, I. (2008). "The Implications of Projected Climate Change for Freshwater Resources and Their Management". Hydrological Sciences Journal, 53(1), 3-10. doi: https://doi.org/10.1623/hysj.53.1.3.

Lentes, P. (2003). "The Contribution of Gis and Remote Sensing to Farming Systems Research on Micro-and Regional Scale in North West Vietnam". In Doppler, W. \& Bauer, S. (Eds.), Farming and Rural System Economics (Vol. 52). Wekersheim: Margraf Verlag.

Liu, Z., \& Liu, L. (2016). "Characteristics and Driving Factors of Rural Livelihood Transition in the East Coastal Region of China: A Case Study of Suburban Shanghai". Journal of Rural Studies, 43, 145-158. doi: https://doi.org/10.1016/j.jrurstud.2015.12.008.

Madhuri, M., Tewari, H. R., \& Bhowmick, P. K. (2014). "Livelihood Vulnerability Index Analysis: An Approach to Study Vulnerability in the Context of Bihar". Jàmbá: Journal of Disaster Risk Studies, 6(1). doi: https://doi.org/10.4102/jamba.v6i1.127.

Mainali, J., \& Pricope, N. G. (2019). "Mapping the Need for Adaptation: Assessing Drought Vulnerability Using the Livelihood Vulnerability Index Approach in a Mid-Hill Region of Nepal". Climate and Development, 11(7), 607-622. doi: https://doi.org/10.1080/17565529.2018.1521329.

McGranahan, G., Balk, D., \& Anderson, B. (2007). "The Rising Tide: Assessing the Risks of Climate Change and Human Settlements in Low Elevation Coastal Zones". Environment and Urbanization, 19(1), 17-37. doi: http://doi.org/10.1177/0956247807076960.

Morzaria-Luna, H. N., Turk-Boyer, P., \& Moreno-Baez, M. (2014). "Social Indicators of Vulnerability for Fishing Communities in the Northern Gulf of California, Mexico: Implications for Climate Change". Marine policy, 45, 182-193. doi: https://doi.org/10.1016/j.marpol.2013.10.013.

Nanlohy, H., Bambang, A. N., Ambariyanto, \& Hutabarat, S. (2015). "Coastal Communities Knowledge Level on Climate Change as a Consideration in Mangrove Ecosystems Management in the Kotania Bay, West Seram Regency". Procedia Environmental Sciences, 23, 157-163. doi: https://doi.org/10.1016/i.proenv.2015.01.024.

Nhuan, M. T., Ngoc, N. T. M., Huong, N. Q., Hue, N. T. H., Tue, N. T., \& Ngoc, P. B. (2009). "Assessment of Vietnam Coastal Wetland Vulnerability for Sustainable Use (Case Study in Xuanthuy Ramsar Site, Vietnam)". Journal of Wetlands Ecology, 2(1), 1-16. doi: https://doi.org/10.3126/jowe.v2i1.1850.

Osbahr, H., Twyman, C., Neil Adger, W., \& Thomas, D. S. G. (2008). "Effective Livelihood Adaptation to Climate Change Disturbance: Scale Dimensions of Practice in Mozambique". Geoforum, 39(6), 1951-1964. doi: https://doi.org/10.1016/j.geoforum.2008.07.010.

Pandey, R., \& Bardsley, D. K. (2015). "Social-Ecological Vulnerability to Climate Change in the Nepali Himalaya". Applied geography, 64, 74-86. doi: https://doi.org/10.1016/j.apgeog.2015.09.008.

Panthi, J., Aryal, S., Dahal, P., Bhandari, P., Krakauer, N. Y., \& Pandey, V. P. (2016). "Livelihood Vulnerability Approach to Assessing Climate Change Impacts on Mixed Agro-Livestock Smallholders around the Gandaki River Basin in Nepal". Regional Environmental Change, 16(4), 1121-1132. doi: https://doi.org/10.1007/s10113-015-0833-y.

Pinto, R., \& Martins, F. C. (2013). "The Portuguese National Strategy for Integrated Coastal Zone Management as a Spatial Planning Instrument to Climate Change Adaptation in the Minho River Estuary (Portugal Nw-Coastal Zone)". Environmental Science \& Policy, 33, 76-96. doi: https://doi.org/10.1016/j.envsci.2013.04.005.

Preston, B. L., Yuen, E. J., \& Westaway, R. M. (2011). "Putting Vulnerability to Climate Change on the Map: A Review of Approaches, Benefits, and Risks". Sustainability Science, 6(2), 177-202. doi: https://doi.org/10.1007/s11625-011-0129-1. 
Rasch, R. J. (2016). "Assessing Urban Vulnerability to Flood Hazard in Brazilian Municipalities". Environment and Urbanization, 28(1), 145-168. doi: https://doi.org/10.1177/0956247815620961.

Rudiarto, I., Handayani, W., \& Sih Setyono, J. (2018). "A Regional Perspective on Urbanization and Climate-Related Disasters in the Northern Coastal Region of Central Java, Indonesia". Land, 7(1). doi: https://doi.org/10.3390/land7010034.

Rudiarto, I., Handayani, W., Wijaya, H. B., \& Insani, T. D. (2018). "Spatial Distribution of Socioeconomic Characteristics in Rural's Java: A Case from Three Different Rural Areas in Central Java". IOP Conference Series: Earth and Environmental Science, 123, 012024. doi: https://doi.org/10.1088/1755-1315/123/1/012024.

Rudiarto, I., Rahmawati, I., \& Sejati, A. W. (2020). "Land Degradation and Community Resilience in Rural Mountain Area of Java, Indonesia". In Shit, P. K., Pourghasemi, H. R., \& Bhunia, G. S. (Eds.), Gully Erosion Studies from India and Surrounding Regions (pp. 449-460). Cham: Springer International Publishing. Retrieved from https://doi.org/10.1007/978-3-030-23243-6 30. doi: https://doi.org/10.1007/978-3-03023243-6 30.

Rudiarto, I., Rengganis, H., Sarasadi, A., \& Caesar, E. (2020). "The Effectiveness of Strategy Adaptations on Tidal Flood in the Coastal Areas of Sayung, Demak, Central Java, Indonesia". IOP Conference Series: Earth and Environmental Science, 448, 012090. doi: https://doi.org/10.1088/1755-1315/448/1/012090.

Shah, K. U., Dulal, H. B., Johnson, C., \& Baptiste, A. (2013). "Understanding Livelihood Vulnerability to Climate Change: Applying the Livelihood Vulnerability Index in Trinidad and Tobago". Geoforum, 47, 125-137. doi: https://doi.org/10.1016/j.geoforum.2013.04.004

Shameem, M. I. M., Momtaz, S., \& Rauscher, R. (2014). "Vulnerability of Rural Livelihoods to Multiple Stressors: A Case Study from the Southwest Coastal Region of Bangladesh". Ocean \& Coastal Management, 102, 79-87. doi https://doi.org/10.1016/j.ocecoaman.2014.09.002.

Shekhar, S., \& Xiong, H. (2007). Encyclopedia of Gis. Berlin: Springer Science \& Business Media.

Smit, B., \& Wandel, J. (2006). "Adaptation, Adaptive Capacity and Vulnerability". Global Environmental Change, 16(3), 282-292. doi: https://doi.org/10.1016/j.gloenvcha.2006.03.008.

Tizale, C. Y. (2007). "The Dynamics of Soil Degradation and Incentives for Optimal Management in the Central Highlands of Ethiopia". (PhD), University of Pretoria. Retrieved from http://hdl.handle.net/2263/25333

Tjoe, Y. (2016). "Measuring the Livelihood Vulnerability Index of a Dry Region in Indonesia: A Case Study of Three Subsistence Communities in West Timor". World Journal of Science, Technology and Sustainable Development, 13(4), 250-274. doi: https://doi.org/10.1108/wjstsd-01-2016-0013.

Tucker, J., Daoud, M., Oates, N., Few, R., Conway, D., Mtisi, S., \& Matheson, S. (2015). "Social Vulnerability in Three High-Poverty Climate Change Hot Spots: What Does the Climate Change Literature Tell Us?". Regional Environmental Change, 15(5), 783-800. doi: https://doi.org/10.1007/s10113-014-0741-6.

Turner, B. L., Kasperson, R. E., Matson, P. A., McCarthy, J. J., Corell, R. W., Christensen, L., . . Schiller, A. (2003). "A Framework for Vulnerability Analysis in Sustainability Science". Proceedings of the National Academy of Sciences, 100(14), 8074-8079. doi: https://doi.org/10.1073/pnas.1231335100.

United Nations Development Programme (UNDP). (2007). "Human Development Report 2007/2008: Fighting Climate Change: Human Solidarity in a Divided World". Retrieved from http://hdr.undp.org/sites/default/files/reports/268/hdr 20072008 en complete.pdf.

Wisner, B., Blaikie, P. M., Blaikie, P., Cannon, T., \& Davis, I. (2004). At Risk: Natural Hazards, People's Vulnerability and Disasters. Psychology Press.

Yoo, G., Kim, A. R., \& Hadi, S. (2014). "A Methodology to Assess Environmental Vulnerability in a Coastal City: Application to Jakarta, Indonesia". Ocean \& Coastal Management, 102, 169-177. doi: https://doi.org/10.1016/j.ocecoaman.2014.09.018.

Zhang, J., \& Goodchild, M. F. (2002). Uncertainty in Geographical Information. London: CRC press.

Zulaykha, S., Subardjo, P., \& Atmodjo, W. (2015). "Pemetaan Daerah Yang Tergenang Banjir Pasang Akibat Kenaikan Muka Air Laut Di Pesisir Kota Tegal". Journal of Oceanography, 4(1), 179-184. 